\title{
Reflections and perceptions of Online Teaching and Learning in Dentistry during COVID-19
}

\author{
Peedikayil, F. C., Chandru, T.P., Kottayi, S., Purakkal, A.T., Ismail, S., John, S.
}

\begin{abstract}
Background: COVID-19 has affected the normal education process all over the world. Today the classes are conducted through online platforms. Therefore a study was conducted to find out the perceptions of dental students and faculty about the online classes.

Methods: Online questionnaire was prepared separately for students and faculty members and was sent to different social media groups and email. The 15 point questionnaire consisted of questions about mode, time of use, satisfaction levels, and overall perceptions of online teaching/ learning apart from the basic demographic details of the participants.

Results: 1550 complete responses from students and 380 responses from faculties were considered. More than $90 \%$ of teachers and students are satisfied with online learning/teaching in the present scenario. Among the faculty and students, there is no statistical difference in the perception of online classes.
\end{abstract}

Conclusion: The need of the hour in this pandemic situation is the continuation of academic activities. Online education has been well accepted by both faculty and students of dentistry.

Keywords: online education, dental education, covid19

\section{Introduction}

The COVID 19 infection caused by Corona virus has affected the humans worldwide. The World Health Organization declared the outbreak a Public Health Emergency of International Concern in January 2020 and more than 16 million people are being affected by this virus (Steffens, 2020).

The coronavirus spreads through close contact, most often through droplets while coughing, sneezing, and talking. People may become infected by touching a contaminated surface and then touching their face (Pascarella et al., 2020; Wu et al., 2020; Velavan et al., 2020).

Department of Pediatric and Preventive Dentistry, Kannur Dental College, Kannur, Kerala, India

Corresponding Author: Faizal C Peedikayil, Department of Pediatric and Preventive Dentistry, Kannur Dental College, Kannur, Kerala, India

Email:drfaizalcp@gmail.com

DOI: http://doi.ora/10.4038/seaime.v14i2.276
The spread of infection can be contained through preventive measures like maintaining distance from other people, wearing a face mask in public, hand washing, cleaning and disinfecting frequently touched objects and surfaces, covering one's mouth when coughing, using sanitizers, avoid crowded places and limit time in enclosed spaces. To contain the virus spread, the governments worldwide have implemented restrictions of travel, lockdowns and closure of mall, public places including educational institutions and place of worship (Kock et al., 2020).

Ever since the lockdown was announced in India in March, the educational institutions have been closed and the students were sent back to their homes. The necessity to maintain social distancing in order to prevent transmission is the factor that affects face to face teaching in institutes. The students accommodated in hostels pose a danger of spread of infection. Even though learning dentistry is a highly skilllearning programme, the only tool available to

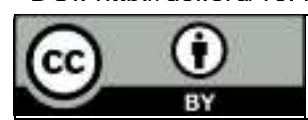
reproduction in any medium, provided the original author and source are credited 
continue education is through online. However optimum skills and practical training does suffer without patient contact and supervision and feedback.

This new method of teaching and learning is a challenge to the teachers as well as students as they have to adapt to the new education system. Therefore a questionnaire study was conducted among the faculty members and students to find their experiences with this new method of theoretical study in dentistry.

\section{Materials and Methods}

Two sets of questionnaires were prepared by the faculty members of the Dept of Pediatric dentistry and it was reviewed and modified by the professors of the same department. The validation of the questionnaire was tested by a pilot study done among two dental colleges in Kerala state in India. The target groups of questionnaire no 1 were dental faculty members working in various levels and the questionnaire no. 2 was designated for the undergraduate (UG) and postgraduates (PG) students studying in various dental colleges across India.

The questionnaire was sent to all teaching institutions in India by email with a request to sent to all faculty and students. Since all colleges has shifted to online mode of education, it is assumed that all faculties and students are using technology in their day to day life. The questionnaire was also sent through google forms to various students and faculty online groups in social media platforms such as Facebook, Facebook messenger, WhatsApp, and Telegram. The inclusion criteria for the study is that all participants should be faculty or student currently pursuing BDS or MDS course from any recognized dental college in India. Interns of dental colleges are excluded from this study.

The sample size for the study was calculated by online software at a confidence level of $95 \%$ and the margin of error at $2.5 \%$, the minimum number of faculty members to be included was 377 for faculty members, and 1534 for students which were rounded to 380 and 1550 respectively.

The questionnaires consisted of 15 questions each about mode and time of use, satisfaction levels, and overall perceptions of online teaching apart from the basic demographic details of the participants. The results were tabulated in percentage according to the no. of responses for each question. The ' $t$ ' values and ' $p$ ' values were obtained to check the significance using Microsoft Excel2019, p-value less than 0.05 was considered significant.

\section{Results}

A total of 1550 complete responses from students and 380 responses from faculties were considered. The sample size accounts to about 10 percent of the total study population in both categories.

Table 1: Demographics of participants

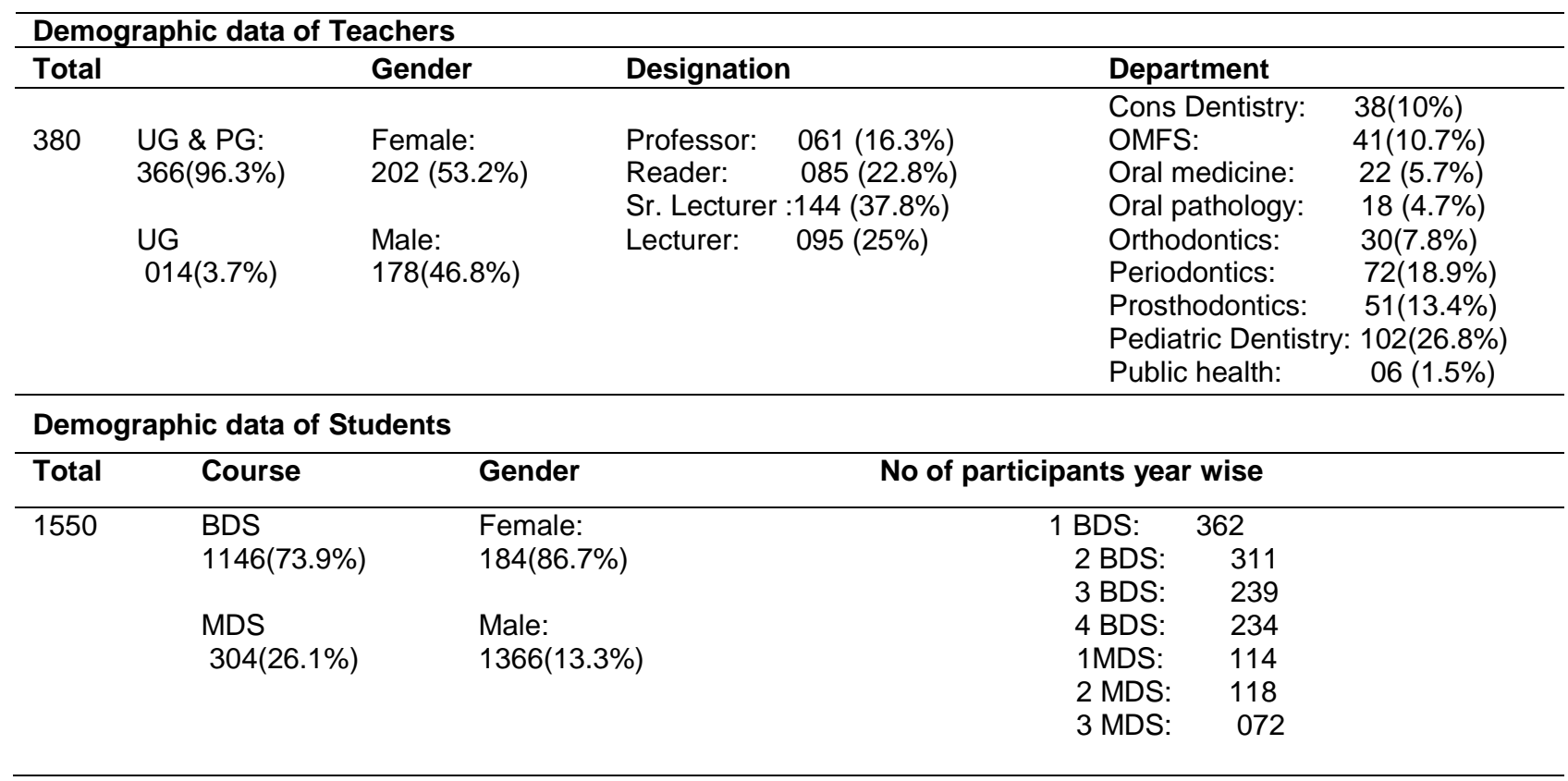


Table 1 shows the demographic details of the respondents. Among the faculty members, $96.3 \%$ of them are teaching $U G$ and $P G$ courses. $46.85 \%$ of respondents were males and $53.15 \%$ of the respondents were females. Even though various department faculty members responded for this questionnaire study, the faculty members from the Dept of Pediatric and Preventive Dentistry constituting the maximum participation at $26.8 \%$. Among students, all batches of undergraduate and postgraduate students took part in the study. Undergraduate students constituted of $73.9 \%$ and postgraduate students being $26.1 \%$. Female students were $86.7 \%$ and male students were $13.3 \%$

Figure 1 shows the online platforms used by the students and faculty. Zoom platform constituted the maximum at $71 \%$ followed by google meet $16 \%$ and the use of other platforms was minimal.

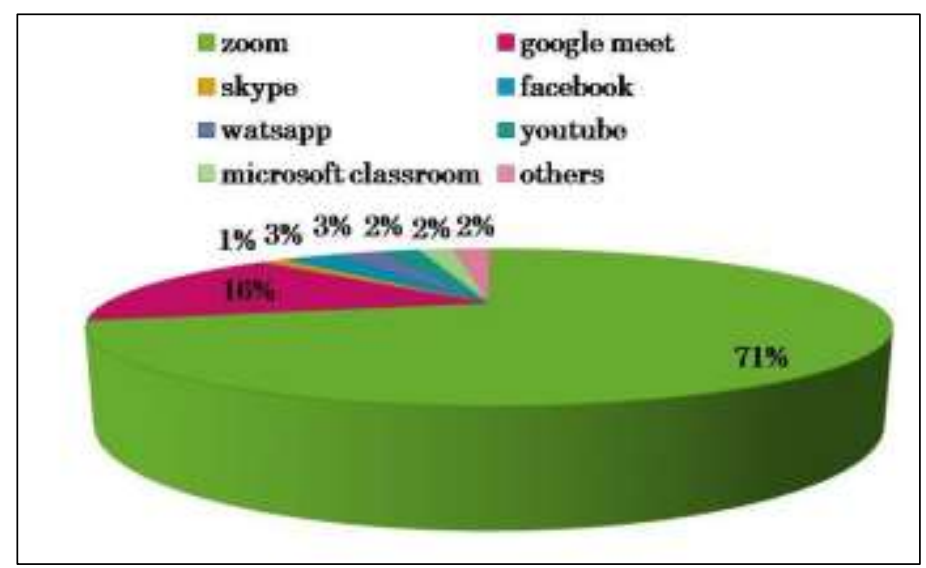

Figure 1: Online platforms used by the students and faculty

Figure 2 shows the devices used by students and the faculty for participating in online classes. Mobile phones use was more among the faculty members and the use of laptops was more among the students. Figure 3 shows the time spent for online studies among the UG and $P G$ students. The results show that majority of UGs and PGs spend 1-2 hours for online studies daily.

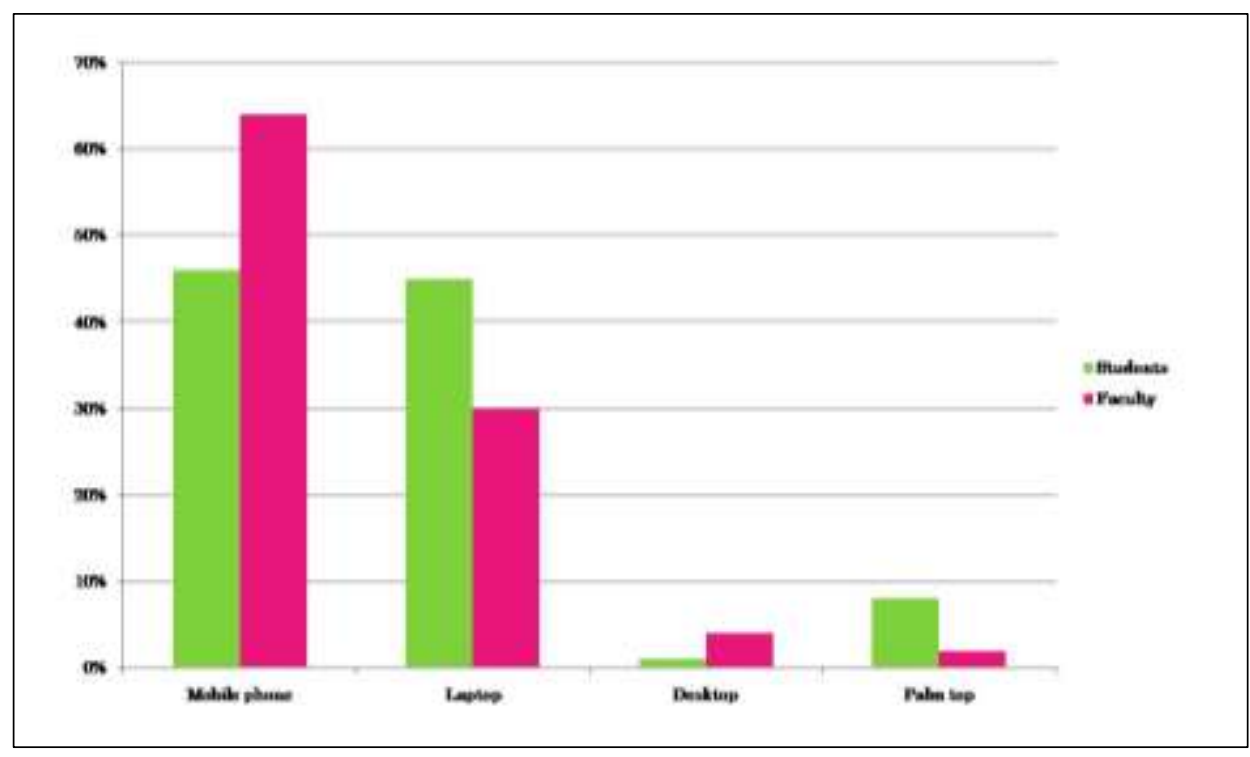

Figure 2: Devices used by students and the faculty 


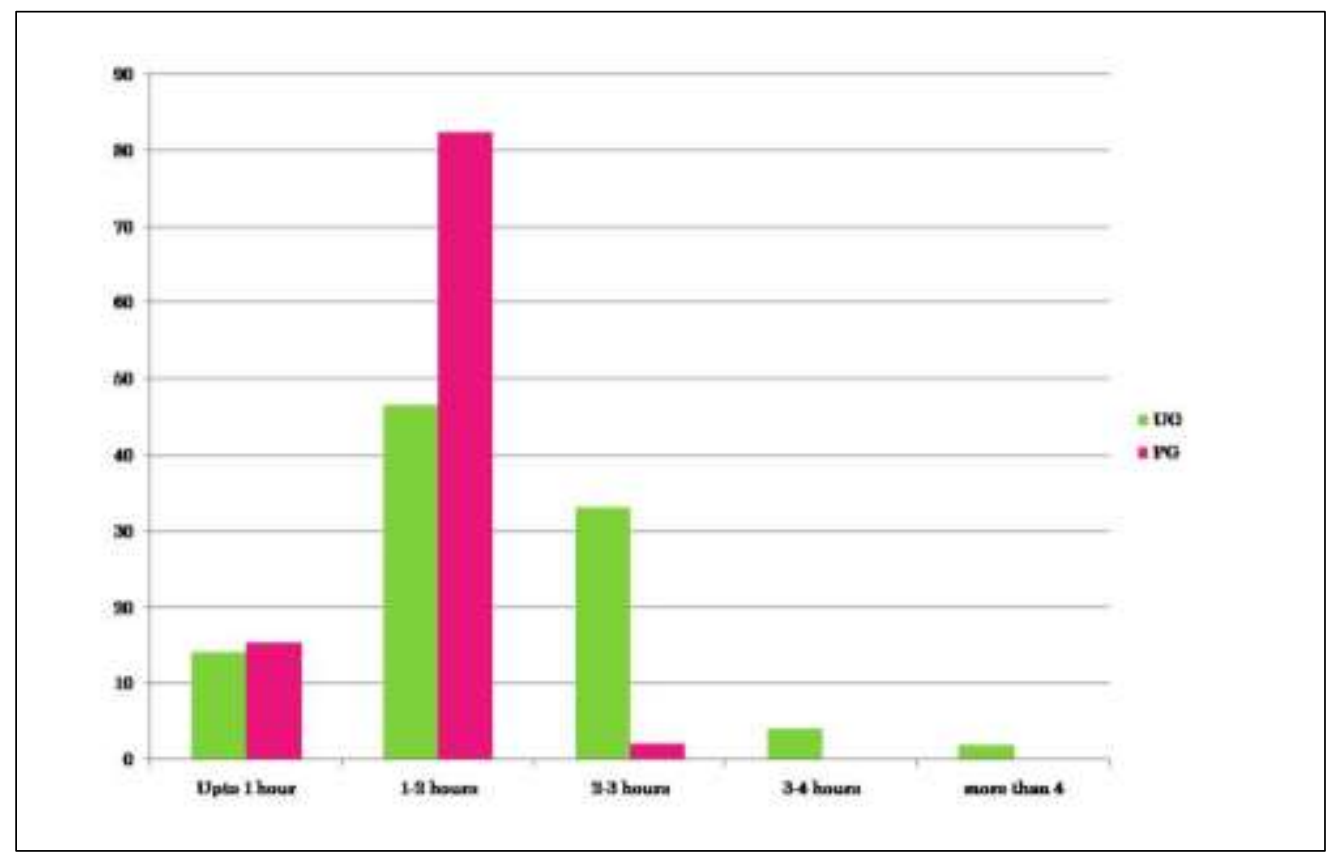

Figure 3: Time spent for online studies among the UG and PG students

Table 2 shows the students' perspectives on online classes. $46 \%$ of the UG student and $65 \%$ of $P G$ students feel that online classes provide a classroom environment. $82 \%$ of the UG students and $96 \%$ of $P G$ students say that they can clear doubts during/after the online classes. $65 \%$ of UG students and $98 \%$ of PG students take notes during the lecture. $88 \%$ of the UG students and $90 \%$ of $P G$ students claim that they gained good theoretical knowledge through online classes. $78 \%$ of UG students prefer to have the handout of the lecture to be shared before the lecture where has only $55 \%$ of PG students opt for it. $44 \%$ of PG students feel that online classes have to be continued even after things are normal whereas only $26 \%$ of UG students feel so. Overall satisfaction among the online classes is $85 \%$ for UGs and 94\% among PGs.

Table 2: Students perception of online classes

\begin{tabular}{lllll}
\hline & \multicolumn{2}{c}{ BDS } & MDS & Nos \\
\cline { 2 - 4 } & Yes & No & $65 \%$ & $45 \%$ \\
\hline $\begin{array}{l}\text { Do you think online class provide classroom } \\
\text { environment }\end{array}$ & $46 \%$ & $54 \%$ & $96 \%$ & $04 \%$ \\
\hline Do you clear doubts in online class & $82 \%$ & $18 \%$ & $98 \%$ & $02 \%$ \\
\hline Do you make notes during lectures & $65 \%$ & $35 \%$ & $90 \%$ & $10 \%$ \\
\hline $\begin{array}{l}\text { Do you think you have gained good theoretical } \\
\text { knowledge through Online classes }\end{array}$ & $88 \%$ & $12 \%$ & $44 \%$ & $56 \%$ \\
\hline $\begin{array}{l}\text { Do you think online classes to be continued even } \\
\text { after things are normal }\end{array}$ & $26 \%$ & $74 \%$ & $55 \%$ & $45 \%$ \\
\hline $\begin{array}{l}\text { Do you feel handouts has to be given prior to } \\
\text { lecture }\end{array}$ & $78 \%$ & $22 \%$ & $90 \%$ & $10 \%$ \\
\hline \begin{tabular}{l} 
Overall satisfaction of online classes \\
\hline
\end{tabular}
\end{tabular}

The $t$-value is -1.47405 . The $p$-value is .166212 .

The result is not significant at $p<.05$.

Table 3 shows the perspective of the faculty members. $88 \%$ of faculty members feel that online classes don't provide a classroom environment. $96 \%$ of faculty members help in clearing the doubts during online classes and $98 \%$ of faculty members feel that students have gained good theoretical knowledge by online classes. $75 \%$ of the faculty members don't want the online classes to be continued after things are back to normal. The table also shows that only $65 \%$ of the faculty members take feedback from students regarding online classes. 
Table 3: Perspective of the faculty members regarding online classes

\begin{tabular}{lcc}
\hline \multicolumn{1}{c}{ Faculty perspective } & \multicolumn{2}{c}{ Responses } \\
\cline { 2 - 3 } & yes & no \\
\hline Do you think online class provide classroom environment & $22 \%$ & $88 \%$ \\
\hline Do you help in clearing doubts in online class & $96 \%$ & $04 \%$ \\
\hline $\begin{array}{l}\text { Do you think your students gained good theoretical } \\
\text { knowledge through Online classes }\end{array}$ & $98 \%$ & $02 \%$ \\
\hline Do you give handouts prior to the class & $10 \%$ & $90 \%$ \\
\hline $\begin{array}{l}\text { Do you evaluate your students during/ after online } \\
\text { classes }\end{array}$ & $18 \%$ & $82 \%$ \\
\hline $\begin{array}{l}\text { Do you think online classes to be continued even after } \\
\text { things are normal }\end{array}$ & $25 \%$ & $75 \%$ \\
\hline $\begin{array}{l}\text { Do you take feedback from students about online } \\
\text { classes }\end{array}$ & $65 \%$ & $45 \%$ \\
\hline
\end{tabular}

The $t$-value is 0 . The $p$-value is .5. The result is not significant at $p<.05$

Table 4 shows the overall rating of online classes by faculty and students on a linear scale from 1-5 with 1 being very poor, 2- poor, 3-satisfactory, 4- good, and 5-very good. Majority of the participants rate the online classes as satisfactory and good.

Table 4: Overall perception of Online classes in percentage responses

\begin{tabular}{|c|c|c|c|c|}
\hline & Students & Faculty & $\mathrm{t}$ value & $p$ value \\
\hline 1. VERY POOR & 4.8 & 0 & \multirow{5}{*}{0.00158} & \multirow{5}{*}{0.999775} \\
\hline 2. POOR & 7.1 & 13 & & \\
\hline 3. SATISFACTORY & 42.9 & 39.2 & & \\
\hline 4. GOOD & 40.5 & 43.5 & & \\
\hline 5. VERY GOOD & 4.8 & 4.3 & & \\
\hline
\end{tabular}

\section{Discussion}

COVID-19 has impacted the education system with regular classroom teaching cancelled in all teaching institutions all over India. But adaptability during the time of challenge is an attribute that any successful human being or system demonstrates more readily. Online learning has its most promising potential and is the most important source of learning in the new normal COVID situation. Implementing technology into medical education in a unique way has allowed students to develop collaborative skills and improve adaptability (Ferrel et al., 2020).

The COVID situation has enabled participants at various locations to communicate with each other with sound and vision as part of their academic necessity (Sidpra et al., 2020). Applications such as Zoom, Microsoft Teams,
WebEx, Google Classroom offer platforms for team-based collaboration. Each application has unique features and most are free for basic use (Kogan et al., 2020). In the present study Zoom platform was the most commonly used online communication media. Zoom ranks high on connectivity, ease of use, security, interactivity, and features such as screen sharing, video record option is available free for short time use, and paid subscriptions for larger groups and more time (Beriswill, 2018).

There is no specific guideline regarding the time for the use of a digital platform. The majority of the participants in this study use it for 1-3 hours daily. The ministry of human resources, Government of India has formulated guidelines for school children wherein the senior school students are advised online learning to be undertaken for not more than four sessions of 30-45 minutes on each daily (Pragyata 
guidelines., 2020). This can be used as a guideline in UG and PG learning also.

Studies show that online education tools have a positive effect as long as the student participates actively (Eom et al., 2018). This study shows that students have adjusted and are satisfied with the online classes.

The students and the faculty feel that students have gained good theoretical knowledge through regular online classes. Moreover high scores of overall satisfaction of online classes were noted in the study.

Although online classes cannot replace the classroom model, it can be added as a compliment and a way to encourage selfdirected learning skills (Bientzle et al., 2019). It is also reported that Online classes have a huge potential for improving soft-skills and research skills which will be helpful for postgraduate students (Rowe et al., 2019). Thirunarayam MO and Prado- AP (Thirunarayanan et al., 2001) compared classroom-based and web-based learning counterparts showed no statistical difference in achievements with better scores for web-based learning. Another study (Verma et al., 2020) shows that students' perception of online classes during COVID showed that $95 \%$ of the participants of pediatric lectures to be enjoyable and interesting.

Whilst online platforms may be sufficient for students in their pre-clinical years but senior students lack exposure to clinical expertise. Virtual Reality (VR) simulation technology is a valuable resource to traditional dental training methods to be considered during the COVID-19 pandemic to enable distance learning. VR simulation has proven to be the most efficient method of teaching within a simulation scenario (Alzahrani et al., 2020).

One of the major drawbacks of the current elearning systems is their inability to keep track of learner's concentration and motivation (Marouane et al., 2015). The absence of teachers face to face presence in online classes leads students to feel free to use phones, surf various web sites, and may lose their focus. With the technological surge, many devices can be used concurrently such as cameras, brain waves, blood oxygen, heartbeat, and blood pressure to detect when students are losing focus to activate an action to get the focus back. Moreover, gadgets and software such as visual attention recognition (VAR), skin temperature recognition, EEG
Signal for attention recognition, etc. have proved to be a definite aid in tracking leaners' concentration (Liu et al ., 2013 ; Sharma et al ., 2018).

In times of social isolation, online education should be seen as a powerful tool that enables educators to continue the delivery of their teaching to students worldwide and which works to ensure a physical distance whilst maintaining social connectivity. In this study which was conducted after three months of lockdown, the results show that both faculties and students have taken this learning process in a very positive manner. Besides, it has also allowed to continue to foster a sense of involvement and communication. As the pandemic situation may last long various innovations can be brought about in online dental education. Program-specific virtual learning platforms have the potential to play an important and useful role in the learning of dental trainees. Moreover, student assessment and feedback regarding the involvement can be translated using various technologies in online learning.

\section{Drawbacks of the study}

The main drawback of our study is that the survey relies entirely on self-reporting, though we assume that the participants completed the survey in an honest and well-thought-out manner, the integrity of our results depend upon the honesty and accuracy of those surveyed. The respondents are from a medical background, so our results may not be generalizable to other educational fields or teaching styles.

\section{Conclusion}

In this pandemic situation wherein social distancing is a norm and no regular classes could be conducted, the virtual learning platform has significantly reshaped and innovated teaching methods for dental students. In times of social isolation, a videoconferencing platform should be seen as a powerful tool that enables educators to continue the delivery of their teaching to students and which works to ensure a physical distance whilst maintaining social connectivity between the teachers and students and also among the peers. 


\section{References}

Alzahrani, S.B., Alrusayes, A.A. and Aldossary, M.S., (2020) Impact of COVID-19 Pandemic on Dental Education, Research, and Students. International Journal of Health Sciences and Research, 10(6), pp.207-212.

Beriswill, J., (2018), Zoom Redefines Web Conferencing for Education. In E-Learn: World Conference on E-Learning in Corporate, Government, Healthcare, and Higher Education (pp. 1208-1211). Association for the Advancement of Computing in Education (AACE).

Bientzle, M., Hircin, E., Kimmerle, J., Knipfer, C., Smeets, R., Gaudin, R. and Holtz, P., (2019) Association of online learning behavior and learning outcomes for medical students: large-scale usage data analysis. JMIR medical education, 5(2), p.e13529.

Eom, S.B. and Ashill, N.J., (2018) A system's view of e-learning success model. Decision Sciences Journal of Innovative Education, 16(1), pp.42-76.

Ferrel, M.N. and Ryan, J.J., (2020) The impact of COVID-19 on medical education. Cureus, 12(3).

Kock, R.A., Karesh, W.B., Veas, F., Velavan, T.P., Simons, D., Mboera, L.E., Dar, O., Arruda, L.B. and Zumla, A., 2020. 2019nCoV in context: lessons learned? The Lancet Planetary Health, 4(3), pp. e87-e88.

Kogan, M., Klein, S.E., Hannon, C.P. and Nolte, M.T., 2020. Orthopaedic education during the COVID-19 pandemic. The Journal of the American Academy of Orthopaedic Surgeons.

Liu, N.H., Chiang, C.Y. and Chu, H.C., (2013) Recognizing the degree of human attention using EEG signals from mobile sensors. Sensors, 13(8), pp.10273-10286.

Marouane, S., Najlaa, S., Abderrahim, T. and Eddine, E.K., (2015) Towards measuring learner's concentration in E-learning systems. International Journal of Computer Techniques, 2(5), pp.27-29.

Pascarella, G., Strumia, A., Piliego, C., Bruno, F., Del Buono, R., Costa, F., Scarlata, S. and Agrò, F.E. (2020). COVID-19 diagnosis and management: a comprehensive review. Journal of Internal Medicine.

Pragyata guidelines (2020). Pragyata guidelines for digital education ministry of human resource development government of India. https://www.mhrd.gov.in/sites/upload_files/ $\mathrm{mhrd} /$ files/pragyata-guidelines_0.pdf

Rowe, M., Osadnik, C.R., Pritchard, S. and Maloney, S., (2019). These may not be the courses you are seeking: a systematic review of open online courses in health professions education. BMC medical education, 19(1), p.356.

Sharma, P., Esengönül, M., Khanal, S.R., Khanal, T.T., Filipe, V. and Reis, M.J., (2018) June. Student Concentration Evaluation Index in an E-learning Context Using Facial Emotion Analysis. In International Conference on Technology and Innovation in Learning, Teaching and Education (pp. 529-538). Springer, Cham.

Sidpra, J., Gaier, C., Reddy, N., Kumar, N., Mirsky, D. and Mankad, K., (2020). Sustaining education in the age of COVID19: a survey of synchronous web-based platforms. Quantitative Imaging in Medicine and Surgery, 10(7), p.1422.

Steffens, I., (2020). A hundred days into the coronavirus disease (COVID-19) pandemic. Eurosurveillance, 25(14), p.2000550.

Thirunarayanan, M.O. and Perez-Prado, A., (2001) Comparing web-based and classroom-based learning: A quantitative study. Journal of Research on Technology in Education, 34(2), pp.131-137.

Velavan, T.P. and Meyer, C.G., (2020). La epidemia de COVID-19. Trop Med Int Health

Verma, A., Verma, S., Garg, P. and Godara, R., (2020). Online Teaching During COVID-19: Perception of Medical Undergraduate Students. Indian Journal of Surgery, 82(3), pp.299-300.

Wu, Y.C., Chen, C.S. and Chan, Y.J., (2020). The outbreak of COVID-19: An overview. Journal of the Chinese Medical Association, 83(3), p.2 